\title{
RANCANG BANGUN SISTEM PENERIMAAN MAHASISWA BARU ONLINE DENGAN MODEL SDLC METODE PROTOTIPE DI UNIVERSITAS ISLAM SYEKH-YUSUF
}

\author{
1Taufik Hidayat \& 2Sukisno \\ Universitas Islam Syekh-Yusuf Tangerang \\ Email:1thidayat@unis.ac.id, 22sukisno@unis.ac.id
}

\begin{abstract}
The online registration model not only makes it easy for prospective new students in the registration service process, the marketing department and BAAK will also get convenience in terms of information on prospective new students, new student data, and the number of prospective new students for each study program or faculty. The new student registration facility online at the PMB website displays some content, namely the registration form, entrance screening card, cost information, information on student activities, information on study areas, and campus service information. The method used in this study is a prototype, where this method describes a business process of an existing information system, but does not go well according to the needs in the field. This prototype method will develop and compile some content and menus that are deemed not to meet the needs. This SIPMB has registration, classification, information, exam time activities and grouping of test results. This SIPMB is able to help these activities more efficiently, realtime, integrity, objectively and online. And the hope is that the results of this study will be developed better with different methods.
\end{abstract}

Keywords: PMB, prototype, marketing, BAAK. 


\begin{abstract}
Abstrak
Model pendaftaran online tidak hanya memudahkan pada calon mahasiswa baru dalam proses pelayanan pendaftaran, bagian marketing dan BAAK akan mendapatkan kemudahan pula dalam hal informasi data calon mahasiswa baru, biodata mahasiswa baru, dan jumah calon mahasiswa baru baik untuk setiap program studi ataupun untuk fakultas. Fasilitas pendaftaran mahasiswa baru online pada website PMB menampilkan beberapa konten yaitu form pendaftaran, kartu ujian saringan masuk, informasi biaya, informasi kegiatan mahasiswa, informasi bidang studi, dan informasi pelayanan kampus. Metode yang digunakan dalam penelitian ini adalah prototipe, dimana metode ini menjabarkan suatu bisnis proses suatu sistem informasi yang sudah ada, namun tidak berjalan dengan baik sesuai dengan kebutuhan di lapangan. Metode prototipe ini akan melakukan pengembangan dan menggubah beberapa konten dan menu yang dianggap tidak sesuai dengan kebutuhan. Dalam SIPMB ini memiliki pendaftaran, klasifikasi, informasi, kegiatan waktu ujian dan pengelompokan hasil ujian. SIPMB ini mampu memperbantu kegiatan tersebut lebih efisien, realtime, teritegritas, obyektif dan online. Dan harapannya hasil penelitian ini akan dapat dikembangkan menjadi lebih baik dengan metode yang berbeda.
\end{abstract}

Kata kunci : $P M B$, prototipe, marketing, $B A A K$. 


\section{A. Pendahuluan}

Sistem Informasi Penerimaan Mahasiswa Baru (SIPMB) adalah salah satu hal terpenting didalam salah satu kegiatan di perguruan tinggi. Penerimaan Mahasiswa Baru disetiap semester sebaiknya harus selalu meningkat dari sebelumnya, oleh karena itu perlu dilibatkan para pegawai perguruan tinggi yang secara profesional dapat menarik calon mahasiswa untuk mendaftar. Setelah proses pendaftaran, perguruan tinggi juga diharuskan dapat menyeleksi calon Mahasiswa yang kompeten dengan melaksanakan ujian tertulis atau ujian lainnya yang mendukung, hal ini dapat berpengaruh terhadap mutu dan kualitas perguruan tinggi kedepannya.

Dengan perkembangan ilmu pengetahuan dan teknologi saat ini, dapat memicu perkembangan sistem online untuk memberikan informasi. Begitu pula perkembangan penerimaan mahasiswa baru yang semakin meningkat dibutuhkan fasilitas pendaftaran secara online. Penerimaan mahasiswa baru sekarang ini banyak dilakukan oleh perguruan tinggi dengan fasilitas online, misalnya di perguruan tinggi Universitas Islam Syekh-Yusuf. Perancangan website yang sedemikian rupa dapat memberikan informasi kepada calon mahasiswa tentang penerimaan mahasiswa baru. Calon mahasiswa baru dapat mengakses informasi dengan mudah dimanapun dan kapanpun.

\section{B. Metode}

SDLC adalah tahapan-tahapan pekerjaan yang dilakukan oleh analis sistem dan programmer dalam membangun sistem informasi. Langkah yang digunakan meliputi:

1 Melakukan survei dan menilai kelayakan proyek pengembangan sistem informasi,

2 Mempelajari dan menganalisis sistem informasi yang sedang berjalan,

3 Menentukan permintaan pemakai sistem informasi,

4 Memilih solusi atau pemecahan masalah yang paling baik,

5 Menentukan perangkat keras (hardware) dan perangkat lunak (software),

6 Merancang sistem informasi baru,

7 Membangun sistem informasi baru,

8 Mengkomunikasikan dan mengimplementasikan sistem informasi baru,

9 Memelihara dan melakukan perbaikan/peningkatan sistem informasi baru bila diperlukan.

System Development Lyfe Cycle (SDLC) adalah keseluruhan proses dalam membangun sistem melalui beberapa langkah. Ada beberapa model SDLC. 
Model yang cukup populer dan banyak digunakan adalah waterfall. Beberapa model lain SDLC misalnya fountain, spiral, rapid, prototyping, incremental, build \& fix, dan synchronize \& stabilize. Dengan siklus SDLC, proses membangun sistem dibagi menjadi beberapa langkah dan pada sistem yang besar, masing-masing langkah dikerjakan oleh tim yang berbeda. Dalam sebuah siklus SDLC, terdapat enam langkah. Jumlah langkah SDLC pada referensi lain mungkin berbeda, namun secara umum adalah sama. Langkah tersebut adalah:

1. Analisis sistem, yaitu membuat analisis aliran kerja manajemen yang sedang berjalan.

2. Spesifikasi kebutuhan sistem, yaitu melakukan perincian mengenai apa saja yang dibutuhkan dalam pengembangan sistem dan membuat perencanaan yang berkaitan dengan proyek system.

3. Perancangan sistem, yaitu membuat desain aliran kerja manajemen dan desain pemrograman yang diperlukan untuk pengembangan sistem informasi.

4. Pengembangan sistem, yaitu tahap pengembangan sistem informasi dengan menulis program yang diperlukan.

5. Pengujian sistem, yaitu melakukan pengujian terhadap sistem yang telah dibuat.

6. Implementasi dan pemeliharaan sistem, yaitu menerapkan dan memelihara sistem yang telah dibuat

Dokumentasi yang baik akan mempermudah pemeliharaan dan peningkatan fungsi system. Metode yang dipergunakan dalam pengembangan perancangan SIPMB ini adalah metode prototype Prototipe adalah satu versi dari sebuah sistem potensial yang memberikan ide bagi para pengembang dan calon pengguna, bagaimana system akan berfungsi dalam bentuk yang telah selesai (Raymond, 2007).

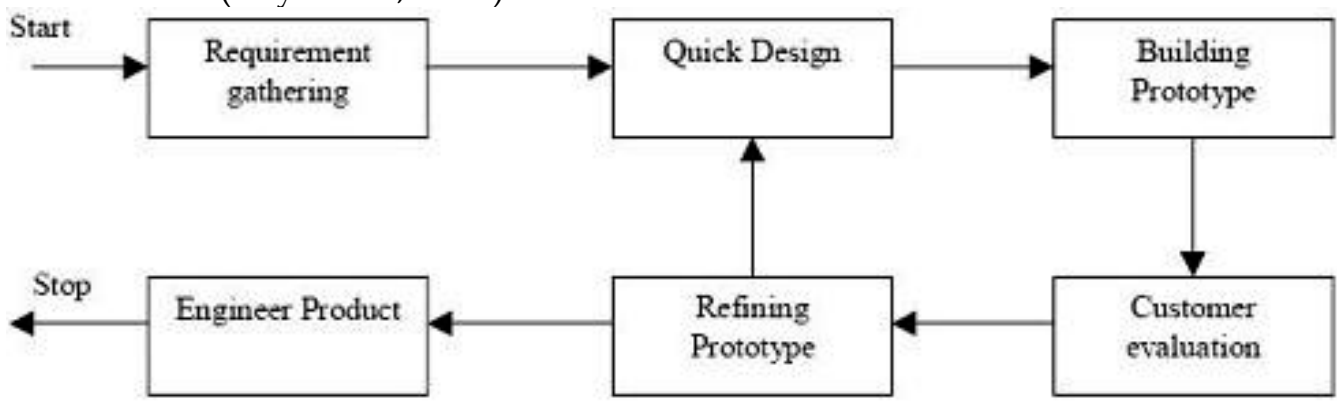

Gambar 2.1 Langkah-langkah Metode Prototipe 
Berikut adalah langkah-langkah dalam merancang sistem yang penulis gunakan dalam mekanisme pengembangan sistem dengan prototype, langkah-langkah tersebut adalah:

1. Mengidentifikasikan kebutuhan pemakai

Analisis sistem mewarnai pemakai untuk mendapatkan gagasan dan apa yang diinginkan pemakai terhadap sistem.

2. Membangun prototype

Analisis sistem mungkin bekerja sama dengan spesialis informasi lainya, menggunakan satu atau lebih peralatan prototype untuk mengembangkan sebuah prototype. Membangun prototyping dengan membuat perancangan sementara yang berfokus pada penyajian pada client.

3. Evaluasi Prototyping

Evaluasi ini dilakukan oleh user apakah prototyping yang sudah dibangun sudah sesuai dengan keinginan pelanggan. Jika sudah sesuai maka langkah 4 akan diambil. Jika tidak prototyping direvisi dengan mengulang langkah 1, 2, dan 3.

4. Pengkodean

Dalam tahap ini prototyping yang sudah di sepakati diterjemahkan ke dalam bahasa pemrograman yang sesuai.

5. Menguji sistem

Setelah sistem sudah menjadi suatu perangkat lunak yang siap pakai, harus di tes dahulu sebelum digunakan. Pengujian ini dilakukan dengan Black Box.

6. Evaluasi Sistem

Pelanggan mengevaluasi apakah sistem yang sudah jadi sudah sesuai dengan yang diharapkan. Jika ya, langkah 7 dilakukan; jika tidak, ulangi langkah 4 dan 5 .

7. Menggunakan sistem

Perangkat lunak yang telah diuji dan diterima client siap untuk digunakan.

\section{Metode Pengumpulan Data}

Metode pengumpulan data digunakan peneliti untuk mendapatkan data sebagai bahan kajian dalam penulisan penelitian ini dengan tujuan membuat suatu rancangan Aplikasi Penerimaan Mahasiswa Baru. Dalam hal ini, peneliti menggunakan metode pengumpulan data sebagai berikut: 
1. Observasi

Teknik observasi yaitu dengan melakukan pengamatan dan pencatatan secara langsung pada business process penerimaan Mahasiswa baru di Universitas Islam Syekh-Yusuf Tangerang khususnya di bagian UPT Humas dan Marketing.

2. Wawancara

Teknik wawancara yaitu dengan cara melakukan tanya jawab secara langsung kepada bagian UPT Humas dan Marketing Universitas SyekhYusuf selaku yang memegang peran penerimaan Mahasiswa baru.

3. Studi Pustaka

Teknik kepustakaan yaitu dengan mengumpulkan data dari buku atau bahan tulisan yang ada relevansinya dengan penelitian ini.

\section{Temuan dan Pembahasan Hasil Penelitian}

\section{Pengujian Sistem Informasi}

Pengujian SIPMB dengan standar ISO 9126 telah dikembangkan dalam usaha untuk mengidentifikasi atribut-atribut kunci kualitas untuk perangkat lunak komputer. Faktor kualitas menurut ISO 9126 meliputi enam karakteristik kualitas sebagai berikut:

1. Functionality (Fungsionalitas). Kemampuan perangkat lunak untuk menyediakan fungsi sesuai kebutuhan pengguna, ketika digunakan dalam kondisi tertentu.

2. Reliability (Kehandalan). Kemampuan perangkat lunak untuk mempertahankan tingkat kinerja tertentu, ketika digunakan dalam kondisi tertentu.

3. Usability (Kebergunaan). Kemampuan perangkat lunak untuk dipahami, dipelajari, digunakan, dan menarik bagi pengguna, ketika digunakan dalam kondisi tertentu.

4. Efficiency (Efisiensi). Kemampuan perangkat lunak untuk memberikan kinerja yang sesuai dan relatif terhadap jumlah sumber daya yang digunakan pada saat keadaan tersebut.

5. Maintainability (Pemeliharaan). Kemampuan perangkat lunak untuk dimodifikasi. Modifikasi meliputi koreksi, perbaikan atau adaptasi terhadap perubahan lingkungan, persyaratan, dan spesifikasi fungsional.

6. Portability (Portabilitas). Kemampuan perangkat lunak untuk ditransfer dari satu lingkungan ke lingkungan lain. 


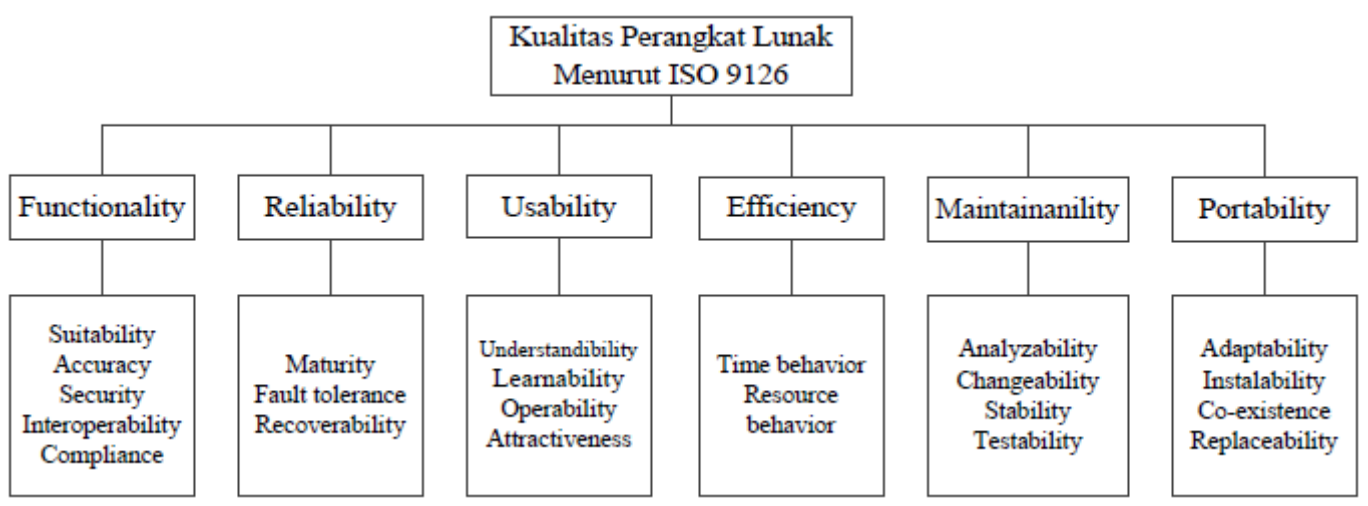

Gambar 2.2. Model Kualitas Perangkat Lunak Model ISO 9126

Sebelum dikembangkan/ dibangun Sistem Penerimaan Mahasiswa Baru berbasis online, model PMB adalah manual dan membutuhkan tenaga yang cukup banyak, di bawah ini adalah beberapa temuan hasil survei terhadap PMB yang awal sebelum dikembangkan/developmen yaitu :

1. Pendaftaran peserta masih menggunakan manual.

2. Calon mahasiswa baru melakukan pendaftaran dengan menulis pada formulir yang telah disediakan.

3. Data calon mahasiswa baru direkam menggunakan excel (manual).

4. UPT Marketing melakukan laporan kepada BAA untuk dilakukan input data calon mahasiswa baru.

5. Generate NIM dilakukan oleh BAA dan UPK, sehingga terjadi penumpukan data mahasiswa.

6. Biodata mahasiswa tidak valid dan tidak lengkap.

7. UPT Marketing tidak memiliki data NIM mahasiswa baru

8. UPT Marketing hanya memiliki copy lembar/formulir isian mahasiswa baru.

9. Untuk pembayaran registrasi menggunakan manual.

\section{Ruang lingkup pengembangan}

Ruanglingkup pengembangan sistem informasi penerimaan mahasiswa baru (SIPMB ) mencakup : 
1 Identifikasi User, berikut ini identifikasi user yang berinteraksi dengan PMB online di lingkungan Universitas Islam Syekh Yusuf.

\begin{tabular}{|c|l|l|}
\hline No & \multicolumn{1}{|c|}{ User } & \multicolumn{1}{c|}{ Kegiatan } \\
\hline 1 & Administrator & $\begin{array}{l}\text { Dapat akses semua modul sistem informasi } \\
\text { pendaftaran mahasiswa baru. }\end{array}$ \\
\hline 2 & Pimpinan & $\begin{array}{l}\text { Dapat akses melihat statistik pendaftar, laporan } \\
\text { pendaftar, laporan registrasi. }\end{array}$ \\
\hline 3 & $\begin{array}{l}\text { Admin } \\
\text { Pendaftaran }\end{array}$ & $\begin{array}{l}\text { Dapat akses konfirmasi pendaftaran, cetak kartu } \\
\text { USM, statistik pendaftar, laporan pendaftar, } \\
\text { laporan registrasi, ranking lulusan, set NIM. }\end{array}$ \\
\hline 4 & Admin Seleksi & $\begin{array}{l}\text { Dapat akses entry nilai pendaftar, laporan } \\
\text { pendaftar, ranking kelulusan. }\end{array}$ \\
\hline 5 & User & $\begin{array}{l}\text { Dapat akses edit password, daftar, data } \\
\text { pendaftar, cetak bukti registrasi, cetak kartu } \\
\text { USM. }\end{array}$ \\
\hline
\end{tabular}

\section{Bisnis Model}

Tabel 4.1. Identifikasi user

Alur proses yang dikembangakan SIPMB yaitu sebelum melakukan pendaftaran melalui Portal PMB Universitas Islam Syekh-Yusuf, alangkah baiknya Calon Mahasiswa mempelajari terlebih dahulu Alur Pendaftaran Mahasiswa Baru Universitas Islam Syekh-Yusuf Tangerang. Berikut ini adalah tata cara atau alur proses pendaftaran Calon Mahasiswa baru. 


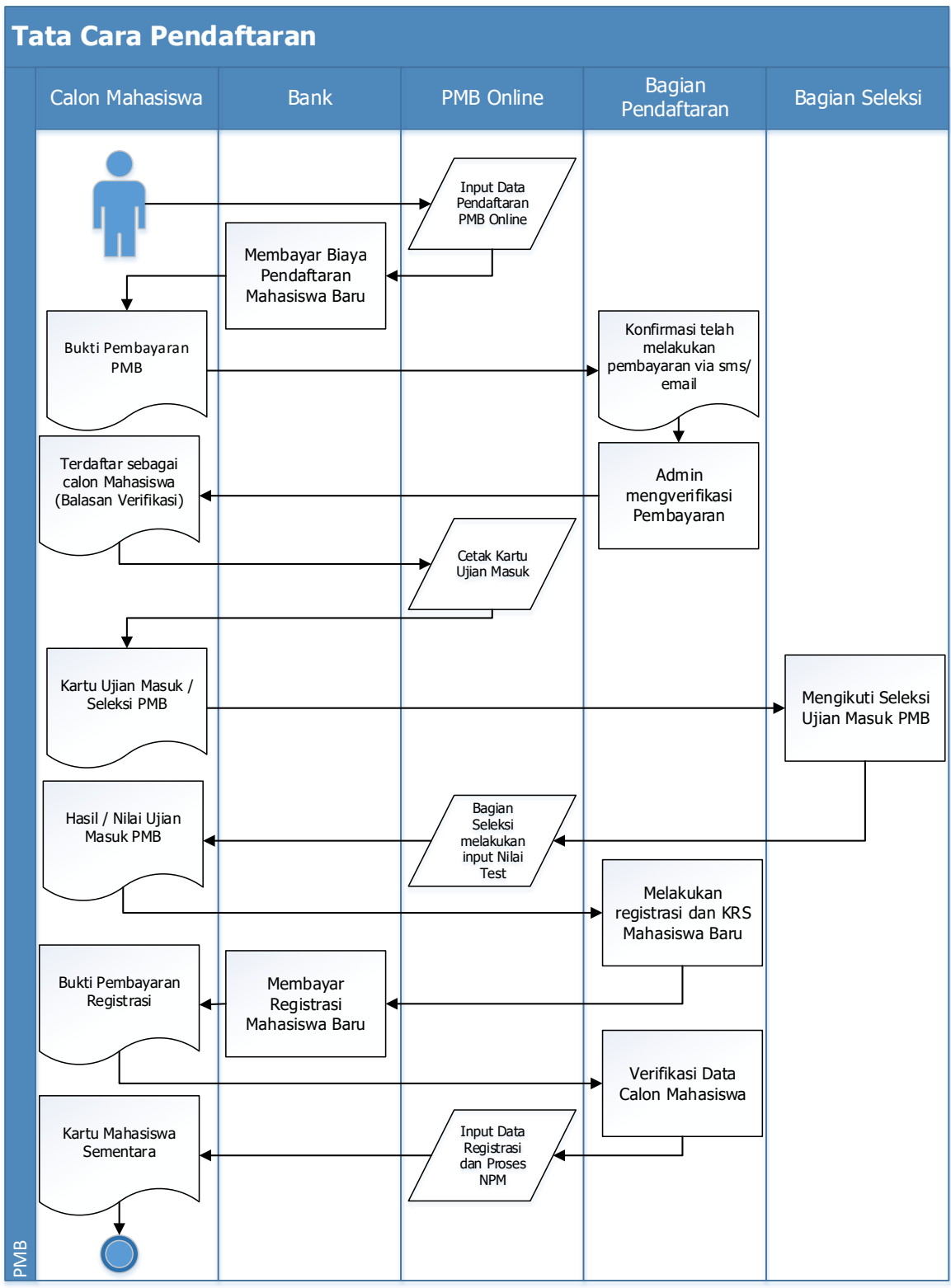

Gambar 4.1. Gambar alur pendaftaran 
Keterangan:

1. Calon Mahasiswa mengunjungi portal pendaftaran di website PMB (pendaftaran mahasiswa baru)

2. Calon Mahasiswa Meng-input Data Pendaftaran PMB Online

3. Calon Mahasiswa membayar biaya pendaftaran Mahasiswa Baru di Bank

4. Calon Mahasiswa mendapat bukti pembayaran PMB

5. Calon Mahasiswa datang ke Bagian Pendaftaran untuk konfirmasi telah melakukan pembayaran via sms/email dan Bagian Pendaftaran melakukan verifikasi pembayaran

6. Calon Mahasiswa menerima balasan verifikasi dari admin pendaftaran dimana Calon Mahasiswa sudah terdaftar

7. Calon Mahasiswa melakukan Cetak Kartu Ujian Masuk pada portal PMB Online

8. Calon Mahasiswa membawa kartu ujian masuk untuk mengikuti seleksi ujian masuk PMB yang di selenggarakan oleh Bagian Seleksi

9. Bagian seleksi melakukan Input Nilai Test di portal PMB Online

10. Calon Mahasiswa dapat melihat hasil atau nilai ujian dengan masuk di portal PMB Online

11. Bagian Pendaftaran melakukan registrasi dan KRS Mahasiswa Baru

12. Calon Mahasiswa membayar Registrasi Mahasiswa baru melalui Bank dan mendapat Bukti Pembayaran Registrasi

13. Bagian Pendaftaran melakukan Verifikasi Data Mahasiswa Baru

14. Bagian Pendaftaran menginput data Registrasi dan memproses NIM (Nomor Induk Mahasiswa)

15. Mahasiswa Baru menerima Kartu Mahasiswa Sementara

16. Selesai

Rencana pengembangan kegiatan dalam pengembangan sistem penerimaan mahasiswa baru online ini menggunakan model SDLC dimana proses pengembangannya menggunakan metode prototipe dasarnya dengan merancang bangun sistem setelah itu dikembangkan ke arah sesuai requaremeny user, jika dinyatakan sesuai dengan requarement user maka sistem tersebut dapat diimplementasikan (live). 
RANCANG BANGUN SISTEM PENERIMAAN MAHASISWA BARU ONLINE DENGAN MODEL SDLC METODE PROTOTIPE DI UNIVERSITAS ISLAM SYEKH-YUSUF

\section{Taufik Hidayat \& Sukisno}

Tabel 4.2. Rencana kerja penelitian

\begin{tabular}{|c|c|c|}
\hline No & Jenis Kegiatan & Waktu \\
\hline 1 & $\begin{array}{l}\text { Persiapan Pengumpulan } \\
\text { Data dan Informasi PMB } \\
\text { online }\end{array}$ & 1 Maret - 30 Maret 2017 \\
\hline 2 & $\begin{array}{l}\text { Bussiness modeling PMB } \\
\text { online }\end{array}$ & 10 Maret - 4 April 2017 \\
\hline 3 & Data modeling PMB online & 28 Maret - 15 April 2017 \\
\hline 4 & Process modeling PMB online & 15 April - 4 Mei 2017 \\
\hline 5 & $\begin{array}{l}\text { Application generation PMB } \\
\text { online }\end{array}$ & 4 Mei - 5 Mei 2017 \\
\hline 6 & $\begin{array}{l}\text { Testing and turnover Online } \\
\text { PMB online }\end{array}$ & 5 Mei - 10 Juni 2017 \\
\hline 7 & $\begin{array}{l}\text { Bussiness modeling PMB } \\
\text { online }\end{array}$ & 10 Juni - 4 Juli 2017 \\
\hline 8 & Data modeling PMB online & 28 Juni - 15 Juli 2017 \\
\hline 9 & Process modeling PMB online & 15 Juli - 4 Agustus 2017 \\
\hline 10 & $\begin{array}{l}\text { Application generation PMB } \\
\text { online }\end{array}$ & 4 Agustus - 5 Agustus 2017 \\
\hline 11 & $\begin{array}{l}\text { Testing and turnover Offline } \\
\text { PMB online }\end{array}$ & 5 Agustus - 10 September 2017 \\
\hline 12 & $\begin{array}{l}\text { Bussiness modeling PMB } \\
\text { online }\end{array}$ & 10 September - 4 November 2017 \\
\hline 13 & $\begin{array}{l}\text { Data modeling Kegiatan dan } \\
\text { Penilaian PMB online }\end{array}$ & 28 September - 15 November 2017 \\
\hline 14 & $\begin{array}{l}\text { Process modeling Kegiatan } \\
\text { dan Penilaian PMB online }\end{array}$ & 15 November - 4 Desember 2017 \\
\hline 15 & $\begin{array}{l}\text { Application generation } \\
\text { Kegiatan dan Penilaian } \\
\text { PMB online }\end{array}$ & 4 Desember - 5 Desember 2017 \\
\hline 16 & $\begin{array}{l}\text { Testing and turnover Offline } \\
\text { Kegiatan dan Penilaian } \\
\text { PMB online }\end{array}$ & 5 Desember 2017 - 10 Januari 2018 \\
\hline 17 & $\begin{array}{l}\text { Penyusunan dan } \\
\text { penyerahan laporan dan } \\
\text { aplikasi }\end{array}$ & 10 Januari - 8 Februari 2018 \\
\hline 18 & Publikasi Penelitian & 9 - 28 Februari 2018 \\
\hline
\end{tabular}


Kebutuhan dan Fungsional dalam pengembangan dan rancangan SIPMB Spesifikasi perangkat lunak

1. Ubuntu 12.04.4 LTS atau Windows

2. Aplikasi dapat dikembangkan berbasis web dengan menggunakan bahasa pemrograman PHP 5.6, database PostgreSQL 9.4 dan web server Apache 2.4

3. Menggunakan Teknologi CSS untuk layout, Jquery dan AJAX untuk client-side validation

Keamanan dan Otentikasi

1. Penanganan Tingkat keamanan web terhadap Cross Scripting XSS, SQL Injection.

2. Penggunaan firewall \& IP restriction dan enkripsi MD5 + SSL untuk login form.

3. Database Load Balancing \& Multi Master Replication (Cluster) untuk menangani akses bersamaan hanya jika diperlukan.

4. Mekanisme Log Audit Trail untuk mencatat (User, IP Address / Host, dan Jenis Aktivitas yang dilakukan).

5. Automatic Backup to storage.

6. Manajemen Hak Akses user sesuai dengan tugas \& fungsinya dan memungkinkan satu user memiliki beberapa role 


\section{Use Case}

Bisnis Model Design Use case use case diagram system informasi penerimaan mahasiswa baru

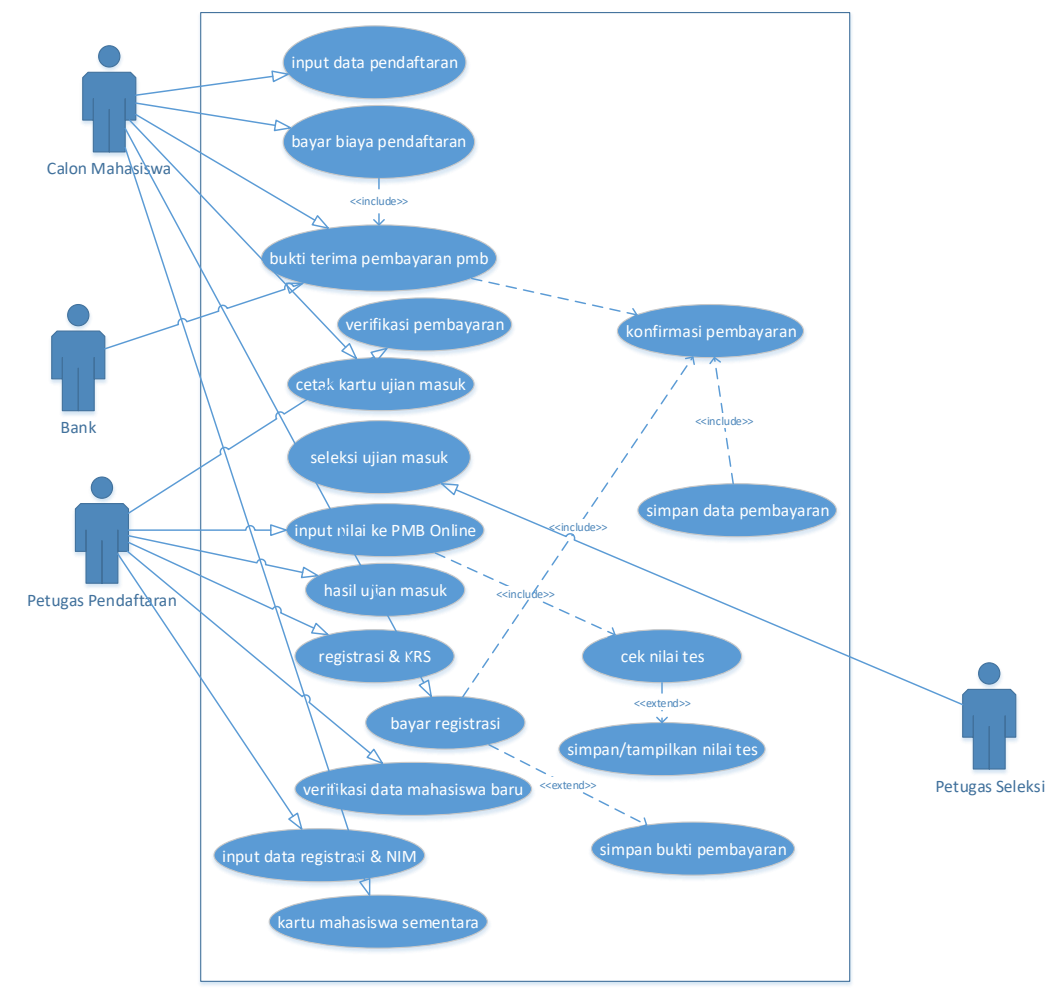

Gambar 4.2. Use case

Dari use case diatas terdapat 4 actor, dan masing-masing actor tersebut mempunyai tugas/tujuan yang berbeda-beda yaitu antara lain:

1. Petugas pendaftaran

Petugas pendaftaran mempunyai tugas memberikan formulir kepada calon pendaftar mahasiswa baru.dan menerima data formulir yang telah diisi oleh calon mahasiswa.

2. Petugas Seleksi

Petugas Seleksi mempunyai tugas memberikan lembar soal test kepada calon mahasiswa baru

3. Bank

Tugasnya yaitu menerima transaksi pembayaran pendaftaran dan pembayaran registrasi Calon Mahasiswa. 


\section{Data Design}

Data Modeling Gambar di bawah ini menunjukan pemodelan database dari SIPMB.

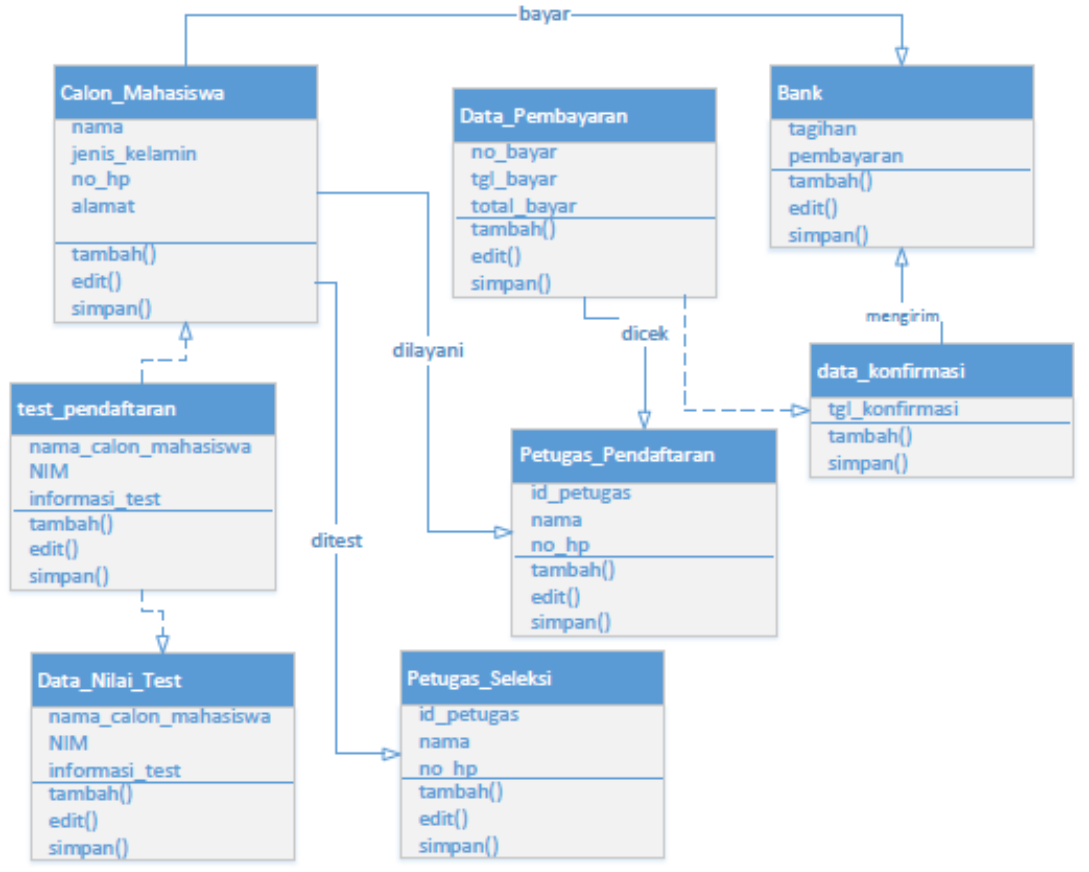

Gambar 4.3. Database

Dari class diagram diatas terdapat 8 class yang memiliki atribut dan method yang berbeda-beda. Adapun class nya yaitu class calon mahasiswa, class data pembayaran, class bank, class data konfirmasi, class petugas pendaftaran, kelas test pendaftaran, class petugas seleksi dan class data nilai test. 


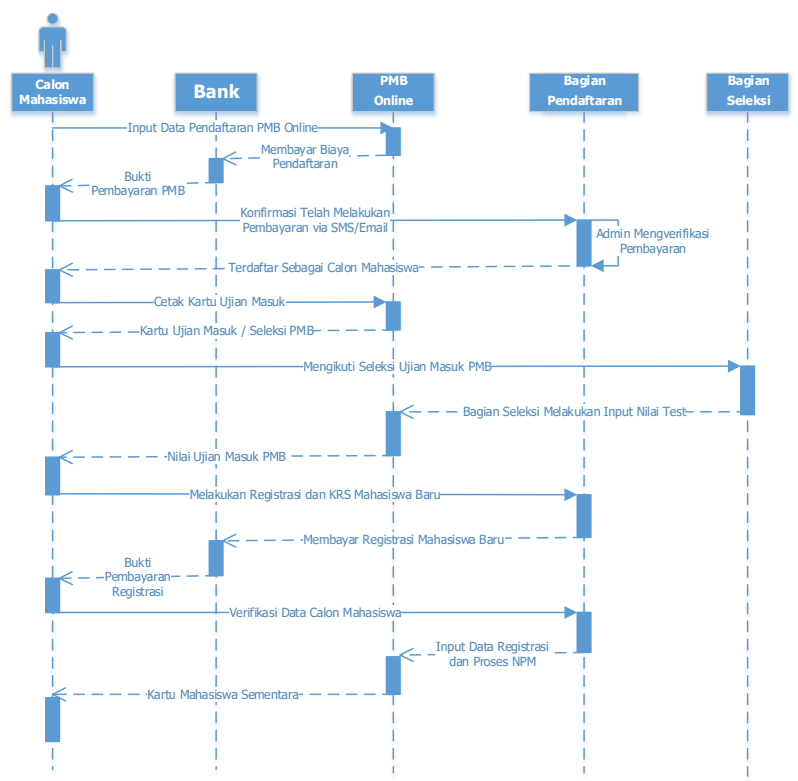

Gambar 4.4. Sequensial diagram

Sequence Diagram Test Calon Mahasiswa Diagram ini merupakan sequence diagram tes calon mahasiswa, menjelaskan Calon Mahasiswa melakukan tes yang diadakan oleh Petugas Seleksi.

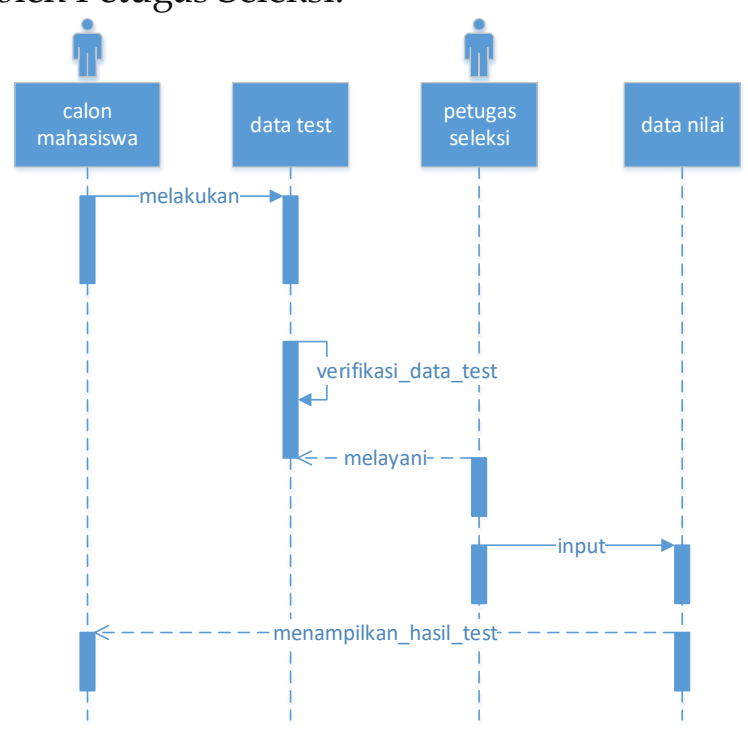

Gambar 4.5. Test case diagram

\section{User Accepted Test}


User aception test merupakan serangkaian proses pada test sistem terhadap user sebelum sistem dipergunakan, dalam melakukan proses UAT ini user akan melakukan test terhadap semua modul yang terdapat di sistem, dan user akan melakukan beberapa jawaban dari hasil tes terhadap sistem.

\section{Tabel 4.3. User Accepted Test (UAT)}

\begin{tabular}{|c|c|c|c|c|}
\hline No & Deskrispi Tes & Gambar & Hasil & Keterangan \\
\hline 1 & $\begin{array}{l}\text { Uji Coba Login } \\
\text { Sebagai Admin } \\
\text { Penjelasan Proses : } \\
\text { 1. Klik Login Area } \\
\text { 2. Masukkan } \\
\quad \text { Username dan } \\
\quad \text { Password }\end{array}$ & 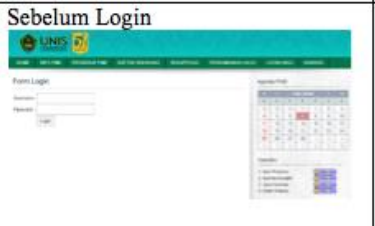 & OK & Sesuai \\
\hline 2 & $\begin{array}{l}\text { Cara Pengaturan } \\
\text { Halaman } \\
\text { Penjelasan Proses : } \\
\text { 1. Login sebagai } \\
\text { Admin } \\
\text { 2. Klik Buat } \\
\text { Halaman di Menu } \\
\text { Admin } \\
\text { 3. Delete / Edit } \\
\text { sesuai keinginan }\end{array}$ & 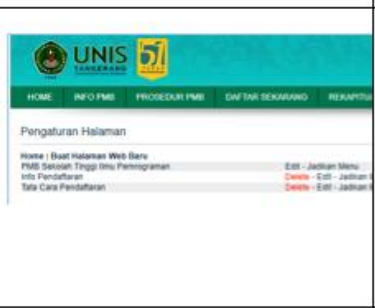 & $\mathrm{OK}$ & Sesuai \\
\hline 3 & $\begin{array}{l}\text { Cara Pengaturan } \\
\text { Menu } \\
\text { Penjelasan Proses : } \\
\text { 1. Login sebagai } \\
\text { Admin } \\
\text { 2. Klik Pengaturan } \\
\text { Menu di Menu } \\
\text { Admin }\end{array}$ & 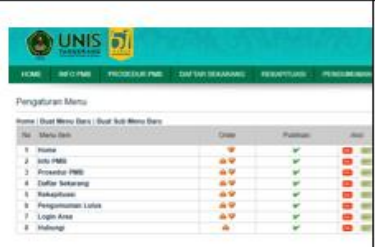 & OK & Sesuai \\
\hline
\end{tabular}

Dalam pengembangan dan perancangan sistem pendaftaran online penerimaan mahasiswa baru memiliki kendala teknis, adapun sistem ini dirancang untuk mengikuti kebutuhan user, dan menjadikan sistem ini userfrendly. Jika ada yang masih memiliki kekeliruan dalam sistem ini akan dilakukan pembahasan dengan user dikemudian pada saat akan dilakukan pengembangan. 


\section{Kesimpulan}

Dari penelitian ini bisa ditarik kesimpulan sebagai berikut:

- Pembuatan dan pengembangan sistem PMB dengan menggunakan model SDLC dengan metode prototipe dengan memiliki dengan alur form pendaftaran, kartu ujian saringan masuk, informasi biaya, informasi kegiatan mahasiswa, informasi bidang studi, dan informasi pelayanan kampus.

- Pengembangan penelitian ini mampu diselesaikan dengan waktu 6 bulan, dengan waktu revisi 3 bulan.

- PMB online ini mampu memperbantu kegiatan penerimaan mahasiswa baru dan memberikan informasi penerimaan mahasiswa secara realtime, teritegritas, obyektif dan online.

Dari hasil penelitian ini diharapkan dan disarankan untuk :

- Pada proses pembayaran masih dalam keadaan manual, dan penelitian kedepannya bisa dikembangan pembayaran secara teritregrasi dengan sistem håßost to host Bank terkait,

- Pengembangan kedepannya dengan difasilitasi dengan website PMB sehingga memudahkan akses dan user-frendly,

- Pengembangan kedepannya dapat mengaplikasikan dengan mobile computing,

- Pada proses metode dapat menggunakan metode lain sesuai dengan model SDLC.

\section{Referensi}

Akbar. (2015). Pengembangan Sistem Menggunakan Model Prototype Pada Sistem Informasi Pemetaan Potensi Pertanian Berbasis Web.

Arinta. (2014). Jurnal Sistem Informasi Akademik Berbasis SMS Gateway Menggunakan Metode Prototype. Jurnal Sistem Informasi Semarang.

Randy. (2013). Aplikasi Pencatatan Aset PDAM Kota Ambon Menggunakan Metode Prototype Dengan Pendekatan Berorientasi Objek. Artikel Ilmiah Pengetahuan.

Raymond. (2007). Sistem Informasi Manajemen. Jakarta: Salemba empat. 